\title{
PENGGUNAAN PERANTI KOHESI DAN KOHERENSI PADA NASKAH DRAMA KARANGAN SISWA KELAS VIII SMPN 7 KOTA BENGKULU
}

\author{
Dio Aristama, Rokhmat Basuki, dan Bambang Djunaidi \\ Program Studi Pendidikan Bahasa dan Sastra Indonesia \\ Jurusan Pendidikan Bahasa dan Seni \\ FKIP Universitas Bengkulu \\ dioaristama@yahoo.com
}

\begin{abstract}
Abstrak
Tujuan penelitian ini adalah untuk melihat dan mendeskripsikan bagaimana penggunaan peranti kohesi dan koherensi pada naskah drama karangan siswa kelas VIII SMPN 7 Kota Bengkulu. Metode yang digunakan dalam penelitian ini adalah metode deskriptif kualitatif. Data dalam penelitian ini berupa naskah drama karangan siswa. Sumber data penelitian ini adalah dialog antartokoh dalam naskah drama karangan siswa. Teknik pengumpulan data menggunakan metode dokumentasi. Teknik analisis data dalam penelitian ini dilakukan melalui langkah-langkah. Uji keabsahan data yang digunakan adalah uji kredibiltas yang dilakukan dengan cara peningkatan ketekunan, dosen pembimbing selama proses bimbingan berlangsung, dan diskusi dengan teman sejawat. Hasil penelitian ditemukan peranti kohesi yang terdapat dalam naskah drama karangan siswa ini yaitu pronomina (kata ganti) terdiri dari (1) Pronomina orang pertama tunggal yaitu saya, dan $a k u$, (2) Pronomina orang pertama jamak yaitu kami, dan kita, (3) Pronomina orang kedua tunggal yaitu kamu, dan kau, (4) Pronomina orang kedua jamak kalian, (5) Pronomina orang ketiga tunggal yaitu dia, (6) Pronomina orang ketiga jamak yaitu mereka, (7) Pronomina petunjuk yaitu di sana, di sini itu, dan ini, (8) Pronomina empunya yaitu $m u$, ku, dan nya. (9) Peranti subtitusi yaitu begitu, itu, seperti itu, dan sama. (10) Peranti elipsis terdapat bagian yang dihilangkan. (11) Peranti konjungsi terdiri dari, konjungsi adversatif yaitu tetapi, konjungsi kasual yaitu karena, konjungsi koordinatif yaitu dan dan atau, konjungsi subordinatif yaitu kalau, konjungsi korelatif yaitu baik/maupun, konjungsi temporal yaitu sebelum. (12) Peranti leksikal terdiri dari pengulangan (repetisi) mengikuti perlombaan, sinonim atau padanan kata ibu/orangtua, antonim atau lawan kata berteman dan bermusuhan. Terdapat sepuluh jenis sarana koherensi dalam naskah drama karangan siswa tersebut diantaranya adalah (1) Sarana koherensi penambahan yaitu dan, juga, (2) Sarana koherensi repetisi atau pengulangan berbicara, (3) Sarana koherensi kontras atau pertentangan yaitu tetapi, (4) Sarana koherensi rentetan atau seri yaitu akhirnya, (5) Sarana koherensi komperasi atau perbandingan yaitu sama saja, (6) Sarana koherensi hasil atau simpulan yaitu jadi, (7) Sarana koherensi sinonim atau padanan kata ibu/orangtua, (8) Sarana koherensi penekanan yaitu malah, (9) Sarana koherensi hubungan sebab akibat yaitu karena, dan (10) Sarana koherensi waktu yaitu waktu itu. Dengan intensitas penggunaan sarana koherensi berbeda satu sama lainnya.
\end{abstract}

Kata kunci: kohesi, koherensi, naskah drama karangan siswa 


\begin{abstract}
The purpose of this study is to see and describe how the use of cohesion and coherency tools in the drama text of students of class VIII SMPN 7 Kota Bengkulu. The method used in this research is descriptive qualitative method. The data in this research is in the form of drama written by students. The source of this research data is the inter-faith dialogue in the student's drama script. Technique of collecting data using documentation method. Data analysis technique in this research is done through steps. Test the validity of the data used is credibility test done by increasing persistence, supervisors during the process of guidance takes place, and discussion with colleagues. The result of the research is found that the cohesion device contained in the student's drama script is pronoun (pronoun) consisting of (1) the first single person pronoun who is saya, and Aku (2) the first person plural pronomina kami, and kita, (3) The second individual pronoun is kamu, and kau (4) the pronoun of your second plural, (5) the singular third person pronoun dia, (6) the third person's plural pronouns they are, (7) the guidance pronoun there, that, and this, (8) The pronouns are mu, ku, and dia. (9) Substitution devices are so, that, that, and the same. (10) The ellipsis device contains the removed part. (11) The conjunction device consists of the adversative conjunction that is but, the casual conjunction that is because, the coordinating conjunction adalah and / or, the subordinate conjunction is that, if, the correlative conjunction is either / or, the temporal conjunction is before. (12) Lexical devices consist of repetition (repetition) following the race, synonyms or maternal / parent, antonym or friendlike and hostile counterparts. There are ten types of means of coherence in the student's drama text are: (1) Coherence means of addition, and, also, (2) Coherence means of repetition or repetition of speech, (3) Coherence means of contrast or contradiction ie but (4) Coherence means (5) Coherence means the result or conclusion is so, (7) Synonym or synonyms coefficient of the word mother / parent, (8) Coherence of suppression means that even , (9) The means of coherence of causal relations is due, and (10) The time coherence means is that time. With the intensity of the use of means of coherence different from each other.
\end{abstract}

\title{
Keywords: cohesion, coherence, drama by student essay
}

\section{PENDAHULUAN}

Wacana adalah rangkaian kalimat yang serasi, yang menghubungkan proposisi satu dengan proposisi lain, kalimat satu dengan kalimat lain, membentuk satu kesatuan. Pengertian satu kalimat dihubungkan dengan kalimat lain dan tidak ditafsirkan satu persatu kalimat saja. Kesatuan bahasa itu bisa panjang bisa pendek. Sebagai sebuah teks, wacana bukan urutan kalimat yang tidak mempunyai ikatan sesamanya, bukan kalimat-kalimat yang dideretkan begitu saja (Eriyanto, $2001: 3$ ).

Wacana yang baik adalah wacana

yang harus memperhatikan hubungan antarkalimat. Hal ini harus selalu diperhatikan untuk memelihara keterkaitan dan keruntutan antarkalimat. Sejalan dengan pandangan bahwa bahasa itu terdiri atas bentuk (form) dan makna (meaning). Kepaduan (kohesi) dan kerapian (koherensi) merupakan unsur hakikat wacana, unsur yang turut menentukan keutuhan wacana. Dalam kata kohesi tersirat pengertian kepaduan, keutuhan, dan kata koherensi terkandung pengertian pertalian dan hubungan. Apabila dikaitkan dengan aspek bentuk dan makna maka dapatlah kita katakan bahwa kohesi mengacu pada aspek bentuk dan koherensi 
kepada aspek makna wacana (Tarigan, 1987 : 96).

Wacana dialog adalah wacana yang dibentuk oleh percakapan atau pembicaraan antara dua pihak seperti terdapat pada obrolan pembicaraan dalam telepon, wawancara, teks drama, dan sebagainya (Darma, 2009 : 26).

Karya sastra dapat dibagi menjadi tiga, yaitu puisi, prosa, dan drama. Terdapat perbedaan penting antara drama dengan bentuk karya sastra yang lain, yaitu di dalam drama terdapat sebuah dialog. Dialog adalah bagian dari naskah drama yang berupa percakapan tokoh satu dengan tokoh yang lainnya dan merupakan perkembangan dari sebuah cerita. Dalam dialog terkandung inti cerita yang ingin disampaikan dalam sebuah drama. Kalimat-kalimat yang digunakan dalam naskah drama harus kohesif dan koheren agar tidak terjadi kesalahan dalam menginterpretasikan maksud dari drama tersebut oleh penonton.

Naskah drama adalah bentuk penyajian dalam tulisan yang disusun sedemikian rupa berdaasarkan alur cerita. Menulis kreatif naskah drama yaitu menuangkan ide dan gagasan yang ada dalam pikiran kedalam sebuah tulisan dari objek yang dilihat atau diamati. Ciri khas naskah drama yakni adanya cakapan atau lakon dalam naskah drama tersebut. Dalam penyusunan dialok ini, pengarang harus benar-benar memperhatikan pembicaraan tokoh-tokoh dalam kehidupan sehari-hari.

Kurikulum yang saat ini berlaku di sekolah-sekolah adalah kurikulum 2013 dan Kurikulum Tingkat Satuan Pendidikan (KTSP). Pembelajaran menulis teks drama di SMPN 7 Kota Bengkulu merupakan pembelajaran yang terdapat pada Kurikulum Tingkat Satuan Pendidikan (KTSP) sesuai dengan silabus dan RPP Kurikulum Satuan Pendidikan teks drama dipeajari di kelas VIII SMP alokasi waktu pembelajaran $2 \times 40$ menit ( 1 pertemuan) siswa ditugskan oleh guru matapelajaran bahasa Indonesia untuk membuat naskah drama karangan siswa-siswi sendiri. Adapun tujuan dari pembelajaran menulis teks drama adalah agar siswa dapat menulis kreatif naskah drama beberapa babak dengan keaslian ide dan siswa dapat menuliskan unsur-unsur yang terdapat dalam naskah drama. Bahasa yang digunakan oleh siswa dalam menulis teks drama juga masih menggunakan bahasa gaul dan bahasa ibu atau bahasa daerahnya. Siswa juga masih kurang memperhatikan kaedah kepenulisanan yang baik dan benar menurut EYD.

Menurut Junaiyah dan Arifin (2010: 24) kohesi merupakan kepaduan bentuk (bahasa), yang secara struktural membentuk ikatan sintaksis. Kohesi dapat dibagi menjadi kohesi gramatikal yang terdiri atas pronomina (kata ganti), substitusi (penggantian), ellipsis, konjungsi, dan leksikal. Sedangkan koherensi ialah pertalian di antara kalimat yang satu dan kalimat yang lain sehingga kalimat-kalimat itu membangun kesatuan makna yang utuh. Wacana yang koherensif memiliki susunan bahasa yang teratur dan amanatnya jalin-menjalin dengan rapi. Sedangkan menurut Mulyana (2005: 26) kohesi adalah hubungan antarbagian dalam teks yang ditandai penggunaan unsur bahasa. Konsep kohesi pada dasarnya mengacu kepada hubungan bentuk, artinya unsur-unsur wacana (kata atau kalimat) yang digunakan untuk menyusun suatu wacana memiliki keterkaitan secara padu dan utuh.

Koherensi adalah keterkaitan antar bagian yang satu dengan yang lainnya, sehingga kalimat memiliki kesatuan makna yang utuh. Sedangkan Setiawan (2011:3.23) mengungkapkan bahwa koherensi merupakan penanda yang difungsikan untuk menghubungkan antarproposisi atau antar kalimat sehingga menjadi sebuah teks yang apik. 
Kohesi dan koherensi dalam naskah drama karangan siswa layak diteliti agar dapat ditemukan variasi penggunaan peranti kohesi dan koherensi, yang berfungsi sebagai alat penghubung antarkalimat yang satu dengan yang lain yang membentuk keterkaitan. Dengan demikian informasi atau hal-hal yang ingin diungkapkan oleh penulis dapat dimengerti dengan mudah oleh pembaca yang membaca naskah drama tersebut, dan sebagai proses pembelajaran untuk siswasiswa SMPN 7 Kota Bengkulu. Kohesi dan koherensi merupakan bagian yang mutlak yang harus ada di dalam suatu tulisan, karena kohesi dan koherensi ini akan mencerminkan isi dari tulisan yang akan dibaca oleh pembaca. Kohesi dan koherensi dapat pula menjadikan tulisan yang dibaca bermakna atau memliki ide atau informasi yang ingin disampaikan penulis kepada pembaca.

Adanya dugaan bahwa terdapatnya peranti kohesi dan koherensi dalam naskah drama karangan siswa menjadikan penelitian ini mengenai kohesi dan koherensi dalam naskah drama karangan siswa. Penelitian ini perlu dilakukan untuk melihat penggunaan peranti kohesi dan koherensi apa saja yang terdapat pada naskah drama karangan siswa SMPN 7 Kota Bengkulu serta seberapa sering peranti tersebut digunakan dalam naskah drama. Judul penelitian ini adalah "Penggunaan Peranti Kohesi dan Koherensi Pada Naskah Drama Karangan Siswa Kelas VIII SMPN 7 Kota Bengkulu."

Berdasarkan latar belakang tersebut maka dirumuskan masalah secara umum bagaimanakah penggunaan piranti kohesi dan koherensi pada naskah drama karangan siswa kelas VIII SMPN 7 Kota Bengkulu?

Secara khusus dirumuskan sebagai

a. Bagaimana penggunaan peranti kohesi yang terdapat pada naskah drama karangan siswa kelas VIII SMPN 7 Kota Bengkulu?

b. Bagaimana kekoherensian yang terdapat pada naskah drama karangan siswa kelas VIII SMPN 7 Kota Bengkulu?

Penelitian ini bertujuan untuk Mengetahui penggunaan peranti kohesi apa saja yang terdapat pada naskah drama karangan siswa kelas VIII SMP Negeri 7 Kota Bengkulu. serta mengetahui kekoherensian pada naskah drama karangan siswa kelas VIII SMP Negri 7 Kota Bengkulu?

\section{METODE}

Penelitian ini menggunakan rancangan penelitian deskriptif kualitatif dengan menggunakan teknik dokumentasi sebagai alat pengumpulan data.

Sumber Data dalam penelitian ini adalah 13 naskah drama karangan siswa kelas VIII SMPN 7 Kota Bengkulu.

Data dalam penelitian ini adalah dialog-dialog yang memiliki peranti kohesi dan koherensi pada naskah drama karangan siswa kelas VIII SMPN 7 Kota Bengkulu. Analisis data menggunakan langkah- langkah berikut, Mengumpulkan data berupa naskah drama karangan siswa kelas VIII SMPN 7 Kota Bengkulu Berjumlah 20 naskah drama karangan siswa melibatkan guru matapelajaran bahasa Indonesia dan penulis dalam pengumpulan data tersebut dari beberapa kelas. Kemudian penulis mengambil naskah drama berjumlah 13 naskah drama karangan siswa karena mempertimbangkan naskah drama yang terkumpul hanya 13 naskah drama yang memenuhi kriteria sedangkan naskah drama yang lainnya tidak memenuhi kriteria. 13 naskah drama tersebut akan mewakili naskah drama yang akan dianalisis penulis nantinya. (2) Pengkodean data setelah data terkumpul, peneliti memberi kode disetiap dialog yang terdapat di dalam naskah drama siswa. 
Pengkodean dilakukan dengan cara memberi nomor untuk setiap dialog-dialog pada naskah drama, untuk memudahkan peneliti dalam menganalisis data nantinya. Cara pengkodean datanya yaitu dengan cara memberi nomor disetiap dialog dengan kode sesuai dengn judul naskah drama contoh: "Teman Mendapat Juara" jadi kode naskah dramanya yaitu TMJ(1) angka satu merupakan angka dialognya. (3) Mengidentifikasi data yang mengandung peranti kohesi dan koherensi pada naskah drama karangan siswa kelas VIII SMPN 7 Kota Bengkulu. (4) Mengklasifikasi data yang mengandung peranti kohesi dan koherensi pada naskah drama karangan siswa kelas VIII SMPN 7 Kota Bengkulu. (5) Menganalisis data yang mengandung peranti kohesi dan kekoherensian naskah drama karangan siswa kelas VIII SMPN 7 Kota Bengkulu. (6) Menyimpulkan hasi analisis yang mengandung peranti kohesi dan kekoherensian pada naskah drama karangan siswa kelas VIII SMPN 7 Kota Bengkulu.

Validitas atau Keabsahan data dalam penelitian ini diperoleh melalui uji kredibilitas (validasi internal).

\section{HASIL DAN PEMBAHASAN}

Berdasarkan hasil penelitian mengenai penggunaan peranti kohesi dan sarana koherensi pada naskah drama karangan siswa kelas VIII SMPN 7 Kota Bengkulu diantaranya penggunaan peranti kohesi terdapat pada pembahasan di bawah ini.

\section{Pronomina Orang Pertama Tunggal (saya)}

Penggunaan peranti kohesi kata ganti orang pertama tunggal saya berfungsi untuk menggantikan nama orang pertama tunggal yang terdapat pada kutipan dialog drama karangan siswa di bawah ini.

TMJ(13) Pak Dimas: "Jujur saja pasti ada yang kamu sembunyikan?"

TMJ(14) Rahmad : "Jujur pak, saya tidak senang Kalau Widya memenangkan perlombaan itu.

TMJ(15) Pak Dimas : "Kamu kenapa?"

TMJ(16) Rahmad : "Karena saya ingin mengikuti perlombaan itu, akan tetapi malah Widya yang dipilih untuk mewakili sekolah."

TMJ(17) Pak Dimas : "Mungkin sekarang bukan kesempatan buat kamu untuk mengikuti perlombaan itu, dan kamu bisa mengkuti perlombaan dilain waktu."

Kutipan dialog pada wacana naskah drama tersebut menjelaskan tentang kekesalan Rahmad terhadap Widya yang memenangkan perlombaan membaca puisi. Dari nomor dialog TMJ(14), TMJ(16) di atas dapat diketahui terdapat pronomina orang pertama tunggal yaitu saya. Pronomina orang pertama tunggal TMJ(14), TMJ (16) saya mengacu kepada (Rahmad) yang kata gantinya saya pada TMJ(14), TMJ(16). Saya tersebut disebut kata ganti endofora. Kata ganti orang pertama tunggal saya ada hubungannya dengan kata ganti orang kedua tunggal yang diajak bicara yaitu kata ganti kamu (Rahmad) terdapat pada dialog TMJ(13), TMJ(15), TMJ(17). Sehingga kata ganti saya, dan kamu merupakan kataganti nama (Rahmad). Tujuan penggunaan kata ganti saya dalam dialog drama karangan siswa adalah untuk menjelaskan atau menggantikan dirinya sendiri dalam sebuah dialog naskah drama karangan siswa (dalam ragam resmi atau biasa). Dengan demikian, kata ganti pada dialog TMJ(14), TMJ(16) saya dan TMJ(13), TMJ(15), TMJ(17) kamu pada dialog drama karangan siswa sebagai penanda yang saling keterhubungan antardialog satu dengan dialog lainnya, sehingga keberadaan pronomina orang pertama tunggal saya dan kamu menjadi peranti yang kohesif dalam dialog drama karangan siswa. 


\section{Orang Pertama Jamak (kami)}

Penggunaan peranti kohesi kata ganti orang pertama jamak kami berfungsi untuk menggantikan nama-nama orang pertama jamak yang terdapat pada kutipan dialog drama karangan siswa di bawah ini.

TMJ(1) Ferdy: "Selamat ya Wid kamu berhasil menjuarai perlombaan membaca puisi."

TMJ(2) Renaldy : "Iya Wid, Kami turut bangga dan senang karena kamu memenangkan perlombaan itu."

TMJ(3) Widya : "Terima kasih teman teman."

TMJ(4) Janiarti :"Wah, kalau begitu harus kita rayakan."

TMJ(5) Ferdy :"Boleh sekali, rencananya kita mau kemana?"

TMJ(6) Renaldy : "Bagaimana kalau kita merayakan dengan makan-makan?" Kutipan dialog pada wacana naskah drama tersebut menjelaskan tentang rencana perayaan atas berhasilnya Widya memenangkan lomba baca puisi. Dari nomor dialog TMJ(2) dapat diketahui terdapat pronomina orang pertama jamak kami. Kata ganti orang pertama jamak pada dialog TMJ(2) kami ada hubungannya dengan kata ganti yang mengacu kepada orang-orang yang berada dalam pembicaraan atau orang yang berada ketika dialog berlangsung. Kami tersebut disebut kata ganti eksofora. Pronomina orang pertama jamak kami, memiliki refren yang sama dengan dialog yang dibicarakan yaitu pada dialog TMJ(4), TMJ(5), TMJ(6) kita merupakan temanteman (Widya) kecuali orang yang diajak berbicara yaitu (Widya) pada dialog TMJ(3). Penggunaan kata ganti kami, dalam dialog drama karangan siswa adalah sebagai pronomina orang pertama jamak seseorang yang berbicara dengan orang lain (tidak termasuk yang diajak berbicara). Dengan demikian, kata ganti pada dialog $\mathrm{TMJ}(2)$ kami dan TMJ(4), $\mathrm{TMJ}(5), \mathrm{TMJ}(6)$ kita dalam naskah drama karangan siswa sebagai penanda yang saling keterhubungan antardialog satu dengan dialog lainnya, sehingga keberadaan pronomina orang pertama jamak kami dan kita menjadi peranti kohesi yang kohesif dalam dialog drama karangan siswa.

\section{Kata Ganti Penunjukan Tempat (di sini) \\ Penggunaan peranti kohesi penunujukan tempat di sini berfungsi untuk menunjukan letak suatu} benda/tempat yang terdapat pada kutipan dialog drama karangan siswa di bawah ini. BPB(3) Riyan : :"Kamu yakin mau nyuri di rumah ini?"

BPB(4) Ikwan :"Ya yakinlah,"

BPB(5) Riyan : :Tapi katanya, di sini itu orangnya pada galak galak,"

BPB(6) Ikwan :"Gini aja, kalo Kamu mau ikut silahkan, tidak juga tidak masalah,"

BPB(7) Riyan :"Okedeh, aku ikut,"

BPB(8) Ikwan :"Nah, gitudong,"

BPB(9) Riyan :"Tapi kalau ketahuan gimana?"

$\mathrm{BPB}(10)$ Ikwan: "Kamu pergi saja kalau kamu

takut."

BPB(11) Ryan: "Iya-iya aku ikut"

Kutipan dialog pada wacana

naskah drama tersebut menjelaskan tentang dua orang yang akan melakukan pencurian disebuah rumah. Dari nomor dialog $\mathrm{BPB}(5)$ dapat diketahui terdapat kata ganti petunjuk tempat di sini, kata tersebut mengacu pada kata "di rumah" yang terdapat dalam tuturan BPB(3). Di sini tersebut kata ganti petunjuk tempat karena di sini itu sama dengan di rumah yang ingin mereka curi. Kata ganti di sini pada dialog drama karangan siswa untuk menggantikan nama tempat yang sebelumnya telah disebutkan pada tuturan sebelumnya yaitu pada dialog $\mathrm{BPB}(3)$, serta letak tempat yang digantikan tersebut dekat dengan pembicara. Jika 
tidak ada atau dihilangkan dialog pertama yaitu pada tuturan "di rumah" maka kalimat kedua di sini menjadi rancu dan tidak jelas maksudnya. Dengan demikian, kata ganti petunjuk tempat $\mathrm{BPB}(5)$ di sini dan $\mathrm{BPB}(3)$ di rumah dalam naskah drama karangan siswa sebagai penanda yang saling keterhubungan antardialog satu dengan dialog lainnya, sehingga keberadaan kata ganti petunjuk tempat $d i$ sini dan di rumah menjadi peranti yang kohesif dalam dialog drama karangan siswa.

\section{Substitusi (begitu)}

Penggunaan peranti kohesi subtitusi begitu berfungsi untuk menunjukan atau menghubungkan antara kata dan makna yang terdapat pada kutipan dialog drama karangan siswa di bawah ini.

ASS(25) Jovan : “Ok Ami, gimana kalau aku coba tanyakan ketante aku barangkali dia butuh karyawan part time."

ASS(26) Dion : "Iya, tante kamu kan punya supermarket."

ASS(27) Linda : "Kyaknya itu ide bagus deh. Kalau tante Jovan emang butuh karyawan part time, kamu kan bisa simpan uang kamu untuk biaya sekolah. Kamu mau kan, Ami?"

ASS(28) Ami : "Baiklah kalau begitu, aku pasti mau kalau tante Jovan emang butuh karyawan part time.'

Kutipan dialog pada wacana naskah drama tersebut menjelaskan tentang rencana teman-teman Ami menyuruh agar Ami bekerja di supermarket tantenya Jovan. Dari nomor dialog ASS(28) dapat diketahui terdapat kata begitu, merupakan kata pengganti yang telah diucapkan pada tuturan dialog sebelumnya "kalau tante jovan emang butuh kariawan part time, kamukan bisa simpan uang kamu untuk biaya sekolah."
Penggantian kata begitu pada dialog drama karangan siswa menjadi kata pengganti dari penjelasan yang telah diungkapkan pada dialog sebelumnya serta kata pada dialog TMJ(4) begitu memiliki makna yang sama dengan kata seperti itu. Penggunaan kata ganti petunjuk begitu pada dialog drama karangan siswa adalah sebagai kata ganti untuk menyatakan atau menunjukkan sesuatu hal yang sedang diucapkan atau dilakukan. Dengan demikian, subtitusi pada dialog ASS(28) begitu dalam naskah drama karangan siswa sebagai penanda yang saling keterhubungan antardialog satu dengan dialog lainnya, sehingga keberadaan subtitusi begitu menjadi peranti yang kohesif dalam dialog drama karangan siswa.

\section{Elipsis (sama Jepri)}

Penggunaan peranti kohesi elipsis sama Jefri berfungsi untuk menunjukan atau menghubungkan antara kata dan makna yang terdapat pada kutipan dialog drama karangan siswa di bawah ini.

SP(19) Cencen: "Situasi yang kurang menyenangkan antara aku sama Jepri. Memngnya kenapa, ada apa antara aku sama Jepri? Aku punya salah (..........)?"

SP(20) Missy: "Begini, menurut Jefri kamu bersikap kurang menyenangkan sama dia? Terus dia bilang kalau kamu itu sombong sama dia."

SP(21) Cencen:" Kenapa kamu bisa

bicaraseperti itu, Jef? Aku punya salah ya? Maaf, kalau aku memang punya salah, tapi aku benar-benar tidak menyadarinya."

SP(22) Missy: "Benar kan, Jef? Cencen

tidak berniat membuat kamu berpikir yang bukan bukan."

SP(23) Guntur: "lya, kamu itu salah paham, Jef."

Kutipan dialog pada wacana naskah drama tersebut menjelaskan 
tentang kesalahpahaman antara Jefri dan Cencen. Dari nomor dialog SP(19) dapat diketahui terdapat kata sama jepri, kata tersebut dihilangkan pada kalimat selanjutnya. Sehingga, dinamakan elipsis. Elipsis tersebut terdapat pada kalimat "aku punya salah?" kata sama Jepri sebenarnya terdapat setelah unsur kalimat "aku punya salah" tetapi dihilangkan karena ujud asalnya dapat diramalkan konteks bahasa atau konteks luar bahasa. Elipsis sama Jefri tersebut menghubungkan kalimat situasi yang kurang menyenangkan antara aku sama Jepri. Memngnya kenapa ada apa antara aku sama Jepri? dan kalimat aku punya salah.? Penggunnaan peranti elipsis atau penghilangan dalam dialog yaitu, untuk menghasilkan kalimat yang efektif, efisiensi dalam pemakaian bahasa, mencapai aspek kepaduan wacana, bagi pembaca atau pendengar berfungsi untuk mengaktifkan pikirannya terhadap hal-hal yang tidak diungkapkan dalam satuan bahasa (untuk kepraktisan berbahasa terutama dalam berkomunikasi secara lisan). Dengan demikian, elipsis atau penghilangan pada dialog SP(19) sama Jepri dalam naskah drama karangan siswa sebagai penanda yang saling keterhubungan antardialog satu dengan dialog lainnya, sehingga keberadaan elipsis atau penghilangan sama Jefri menjadi peranti yang kohesif dalam dialog drama karangan siswa.

\section{Konjungsi Adversatif (tetapi)}

Penggunaan peranti kohesi

konjungsi adversatif tetapi terdapat pada

kutipan dialog drama karangan siswa di bawah ini.

TMJ(13) Pak Dimas: "Jujur saja pasti ada yang kamu sembunyikan?"

TMJ(14) Rahmad : "Jujur pak, saya tidak snang kalau Widy memenangkan perlombaan itu."

TMJ(15) Pak Dimas : "Kamu kenapa?"

TMJ(16) Rahmad : "Karena saya ingin mengikuti perlombaan itu akan

tetapi malah Widya yang dipilih

untuk mewakili sekolah."

TMJ(17) Pak Dimas : "Mungkin sekarang

bukan kesempatan buat kamu

untuk mengikuti perlombaan itu, dan kamu biasa mengkuti

perlombaan dilain waktu."

TMJ(18) Rahmad : "Ya pak saya mengerti."

Kutipan dialog pada wacana naskah drama tersebut menjelaskan tentang kekesalan Rahmad terhadap Widya yang memenangkan perlombaan membaca puisi. Dari nomor dialog $\mathrm{TMJ}(16)$ dapat diketahui terdapat konjungsi adversatif tetapi, konjungsi tersebut menghubungkan tuturan dalam sebuah dialog drama. Konjungsi adversatif merupakan konjungsi yang memarkahi makna yang berhubungan dengan pertentangan atau perbedaan. Konjungsi adversatif tersebut menghubungkan tuturan dialog sebelumnya "Jujur pak, saya tidak snang kalau Widy memenangkan perlombaan itu." Pada dialog tersebut kata tetapi merupakan pertentangan (Rahmad), karena ia ingin mengikuti perlombaan membaca puisi malah Widya yang terpilih untuk mewakili sekolah. Dikatakan juga pada dialog pertama bawa (Rahmad) tidak senang kalau (Widya) yang memenangkan perlombaan itu. Kata pada dialog TMJ(16) tetapi merupakan kohesi kontras sebagai penghubung antara tuturan dialog sebelumnya. Penggunaan peranti kohesi konjungsi adversatif tetapi pada naskah drama karangan siswa adalah sebagai kata penghubung interakalimat untuk menyatakan hal yang bertentangan atau tidak selaras. Dengan demikian, penambahan pada dialog TMJ(16) tetapi dalam naskah drama karangan siswa sebagai peranti yang saling keterhubungan antardialog satu dengan dialog lainnya, sehingga kohesi konjungsi 
adversatif tetapi menjadi peranti yang kohesif dalam naskah drama karangan siswa.

Repetisi atau Pengulangan Kata yang Sama (mengikuti perlombaan)

Penggunaan peranti kohesi repetisi atau pengulangan kata yang sama mengikuti perlombaan terdapat pada kutipan dialog drama karangan siswa di bawah ini.

TMJ(14) Rahmad : "Jujur pak, saya tidak snang kalau Widy memenangkan perlombaan itu."

TMJ(15) Pak Dimas : “Kamu kenapa?"

TMJ(16) Rahmad : "Karena saya ingin mengikuti perlombaan itu, akan tetapi malah widya yang dipilih untuk mewakili sekolah."

TMJ(17) Pak Dimas: "Mungkin sekarang bukan kesempatan buat kamu untuk mengikuti perlombaan itu, dan kamu bisa mengkuti

perlombaan dilain waktu."

TMJ(18) Rahmad : "Ya pak saya mengerti."

Kutipan dialog pada wacana

naskah drama tersebut menjelaskan tentang kesalahpahaman antara Jepri dan Cencen. Dari nomor dialog TMJ(16), TMJ(17) dapat diketahui terdapat pengulangan (repetisi) kata mengikuti perlombaan, Pengulangan (repetisi) merupakan jenis kohesi leksikal yang berwujud pengulangan unsur yang telah disebutkn pada tuturan sebelumnya. Pengulanga kata yang sama pada dialog di atas yaitu pada dialog (Pak Dimas) TMJ(17) dengan (Rahmad) TMJ(16). Kata pada dialog TMJ(16), TMJ(17) mengikuti perlombaan di atas merupakan pengulangan kata yang sama bertujuan memperjelas kembali pertanyaannya yang diungkapkan pada tuturan dialog sebelumnya. Penggunaan peranti leksikal pengulangan atau repetisi seluruh kata atau bentuk lain yang diulang memiliki arti kata yang sama. Dengan demikian, pengulangan atau repetisi pada dialog $\mathrm{TMJ}(16), \mathrm{TMJ}(17)$ mengikuti perlombaan dalam naskah drama karangan siswa sebagai peranti yang saling keterhubungan antardialog satu dengan dialog lainnya, sehingga pengulangan atau repetisi mengikuti perlombaan menjadi peranti yang kohesif dalam dialog drama karangan siswa.

Berdasarkan hasil penelitian mengenai penggunaan peranti kohesi dan sarana koherensi pada naskah drama karangan siswa kelas VIII SMPN 7 Kota Bengkulu diantaranya penggunaan sarana koherensi terdapat pada pembahasan di bawah ini.

\section{Koherensi Repetisi atau Pengulangan (bicara)}

Penggunaan sarana koherensi repetisi atau pengulangan bicara terdapat pada kutipan dialog drama karangan siswa di bawah ini.

ASS(18) Linda : "Tidak tahu si Ami ini.. aku yakin dia pasti lagi ada masalah, tapi tidak tahu kenapa dia tidak mau bicara, padahal kita ini kan sahabat. Jadi bagimana begitu kalau ada seorang sahabat yang tidak terbuka seperti ini."

ASS(19) Ami : "Sebenarnya aku tidak mau bicara masalah aku, karena aku tidak mau kalian ikut terlibat dalam masalah aku, tapi karena kalian memaksa aku untuk bicara, maka aku tidak punya pilihan."

ASS(20) Mimi : "lya, nggap apa-apa, kamu bicara saja!"

ASS(21) Ami : "Aku akan berhenti sekolah."

Dari nomor dialog ASS(18), ASS(19), ASS(20) dapat diketahui terdapat sarana koherensi berupa repetisi atau pengulangan kata dalam dialog di atas yaitu bicara. Kutipan dialog pada wacana naskah drama tersebut menjelaskan 
tentang Ami sedang ada masalah sehingga dia akan berhenti sekolah. Untuk menganalisis data di atas dapat menggunakan teknik baca markah. Pada nomor dialog ASS(19) kata bicara merupakan pengulangan kata dialog (Ami) pada kalimat "sebenarnya aku nggak mau bicara maslah aku, karena aku nggak mau kalian ikut terlibat dalam maslah aku, tapi karena kalian memaksa aku untuk bicara, maka aku nggak punya pilihan" pada dialog tersebut kata bicara diucapkan duakali pada dialog (Ami) pada dialog ASS(19) dan diulangkan kembali pada tuturan dialog (Mimi) pada dialog ASS(20). Penggunaan sarana koherensi pengulangan atau repetisi seluruh kata atau bentuk lain yang diulang memiliki arti kata yang sama. Dengan demikian, sarana penambahan pada dialog ASS(18), ASS(19), ASS(20) bicara dalam naskah drama karangan siswa sebagai sarana yang saling keterhubungan antardialog satu dengan dialog lainnya, sehingga koherensi pengulangan bicara menjadi sarana yang koheren dalam naskah drama karangan siswa.

\section{Koherensi Penambahan (dan)}

Penggunaan sarana koherensi penambahan dan terdapat pada kutipan dialog drama karangan siswa di bawah ini. AST(32) Dini : "Kenapa Bud? Kamu dihukum juga?"

AST(33) Budi : "Tidak, aku ingin menjalani hukuman kalian. Kita sahabat kan? Aku ingin kita bersama"

AST(34) Sita : "Aku berharap ini menjadi pelajaran kita semua"

AST(35) Dini : "dan tidak kita ulangi lagi"

AST(36) Adi : "Kita sahabat sejati"

Dari nomor dialog AST(35) dapat

diketahui terdapat sarana koherensi berupa repetisi atau pengulangan kata dalam dialog di atas yaitu dan. Kutipan dialog pada wacana dialog naskah drama tersebut menjelaskan tentang persahabatan sejati. Untuk menganalisis data di atas dapat menggunakan teknik baca markah. Pada dialog AST(35) penambahan dan merupakan penambahan kata pada dialog Sinta "aku berharap ini menjadi pelajaran kita semua" ditambahkan kata dan pada dialog AST(25) (Dini) "dan tidak kita ulangi lagi" Sarana penghubung berupa penambahan dan dalam dialog drama karangan siswa digunakan untuk menghubungkan satuan bahasa dalam dialog yang memiliki jenis yang setara atau sama seperti yang terdapat di dalam dialog naskah drama karangan siswa. Dengan demikian sarana penghubung pada dialog AST(35) dan dalam naskah drama karangan siswa sebagai sarana yang saling keterhubungan antardialog satu dengan dialog lainnya, sehingga penambahan dan menjadi sarana yang koheren dalam dialog drama karangan siswa.

\section{Koherensi kontras atau pertentangan (tetapi)}

Penggunaan sarana koherensi kontras atau pertentangan tetapi terdapat pada kutipan dialog drama karangan siswa di bawah ini.

TMJ(14) Rahmad: "Jujur pak, saya tidak snang kalau Widy memenangkan perlombaan itu."

TMJ(15) Pak Dimas: "Kamu kenapa?"

TMJ(16) Rahmad: "Karena saya ingin mengikuti perlombaan itu, akan tetapi malah Widya yang dipilih untuk mewakili sekolah."

TMJ(17) Pak Dimas: "Mungkin sekarang bukan kesempatan buat kamu untuk mengikuti perlombaan itu, dan kamu bisa mengkuti perlombaan dilain waktu."

Dari nomor dialog TMJ(16) dapat diketahui terdapat sarana koherensi berupa kontras atau pertentangan dalam dialog di atas yaitu tetapi. Kutipan dialog pada wacana naskah drama tersebut menjelaskan tentang kekesalan Rahmad 
terhadap Widya yang memenangkan perlombaan membaca puisi. Untuk menganalisis data di atas dapat menggunakan teknik baca markah. Pada dialog TMJ(16) kata tetapi merupakan sarana kontras atau pertentangan pada dialog (Rahmad) "karena saya ingin mengikuti perlombaan itu, akan tetapi malah Widya yang dipilih untuk mewakili sekolah" pada dialog tersebut kata pada dialog TMJ(16) tetapi merupakan pertentangan Rahmad karena ia ingin mengikuti perlombaan membaca puisi malah Widya yang terpilih untuk mewakili sekolah. Dikatakan juga pada tuturan dialog pertama TMJ(14) bawa "saya tidak senang kalau Widya yang memenangkan perlombaan itu" kata pada dialog TMJ(16) tetapi merupakan koherensi kontras sebagai penghubung antara dialog sebelumnya. Penggunaan sarana koherensi kontras atau pertentangan tetapi pada naskah drama karangan siswa adalah sebagai kata penghubung interakalimat untuk menyatakan hal yang bertentangan atau tidak selaras. Dengan demikian, sarana penambahan dialog SP(28) tetapi dalam naskah drama karangan siswa sebagai sarana yang saling keterhubungan antardialog satu dengan dialog lainnya, sehingga koherensi kontras atau pertentangan tetapi menjadi sarana yang koheren dalam naskah drama karangan siswa.

\section{Koherensi Rentetan atau Seri (akhirnya)}

Penggunaan sarana koherensi rentetan atau seri akhirnya terdapat pada kutipan dialog drama karangan siswa di bawah ini.

SP(27) Jefri: "Maafkan aku ya, Cen.. aku sudah salah menilai mu."

SP(28) Cencen: "Iya, tidak mengapa. Aku juga minta maaf karena sudah membuat kamu berpikir yang bukan-bukan. Kita ini kan sahabat, dan akan terus menjadi sahabat."
SP(29) Guntur: "Alhamdulillah.. akhirnya mereka saling menyadari satu sama lain."

SP(30) Missy: "Persahabatan merupakan salah satu hal terpenting dalam kehidupan kita. Jangan menodai persahabatan kalian hanya karena salah paham."

Dari nomor dialog SP(29) dapat diketahui terdapat penanda koherensi berupa rentetan atau seri dalam dialog di atas yaitu akhirnya. Kutipan dialog pada wacana naskah drama tersebut menjelaskan tentang dua sahabat yang saling meminta maaf karena menyadari kesalahan mereka masing-masing. Menganalisis data di atas dapat menggunakan teknik baca markah. Pada dialog SP(29) kata akhirnya merupakan rentetan atau seri pada dialog Guntur "Alhamdulillah.. akhirnya mereka saling menyadari satu sama lain." pada dialog tersebut kata akhirnya merupakan rentetan atau seri pada dialog sebelumnya yaitu pada dialog Jepri dan Cencen, akhirnya mereka berdua sama-sama saling menyadari kesalahan mereka. kata akhirnya merupakan koherensi rentetan yang menjadi sarana penghubung antardialog. Penggunaan sarana koherensi rentetan akhirnya, pada naskah drama karangan siswa adalah untuk menunjukkan kepada kesimpulan akhir dari dialog antartokoh yang telah diujarkan pada dialog sebelumnya. Dengan demikian, sarana penambahan pada dialog SP(29) akhirnya dalam naskah drama karangan siswa sebagai sarana yang saling keterhubungan antardialog satu dengan dialog lainnya, sehingg koherensi rentetan atau seri akhirnya menjadi sarana yang koheren dalam naskah drama karangan siswa. 
Koherensi Hasil atau Simpulan (jadi)

Penggunaan sarana koherensi hasil atau simpulan jadi terdapat pada kutipan dialog drama karangan siswa di bawah ini. SP(1) Guntur: "Kemarin aku tidak lihat kamu datang di acaranya Cencen, Jef? Kenapa? Kamu ada urusan penting atau kenapa."

SP(2) Jefri: "Aku di rumah saja. Tidak ada apa-apa."

SP(3) Guntur: "Terus kenapa kamu tidak datang? Seharusnya kamukan bisa datang soalnya kamu juga tidak ada kesibukan apa-apa waktu itu?"

SP(4) Missy: "Maaf ya, Jef aku ikut bicara ya?"

SP(5) Guntur: "Emangnya ada apa, mis? Apa kamu lagi ada masalah sama Cencen, Jef? Masalah apa? Kenapa kamu tidak bicara sama aku?"

SP(6) Missy: "Jefri bilang sama aku kalau Cencen sombong sama dia katanya. Jadi, dia tidak ingin ambil tahu lagi soal Cencen."

SP(7) Guntur: "Aku tidak percaya. Kamu pasti salah paham! Cencen itukan orangnya baik. Aku sudah bertahun-tahun kenal sama dia. Selama kenal dia aku tidak pernah merasa kalau dia itu orangnya sombong."

Dari nomor dialog SP(6) dapat diketahui terdapat sarana koherensi berupa hasil atau simpulan dalam dialog di atas yaitu jadi. Kutipan dialog pada wacana naskah drama tersebut menjelaskan tentang kesalahpahaman Jefri terhadap sahabatnya sendiri yaitu Cencen yang dianggapnya sombong. Untuk menganalisis data di atas dapat menggunakan teknik baca markah. Pada dialog SP(6) kata jadi merupakan hasil atau simpulan pada dialog Missy "Jepri bilang sama aku kalu Cencen sombong sama dia katanya. Jadi, dia tidak ingin ambil tahu lagi soal Cencen." pada dialog tersebut kata jadi merupakan hasil atau simpulan karena pada dialog petama Guntur menanyakan bahwa kalau Guntur tidak melihat Jepri di acaranya Cencen, karena hal itulah Jepri tidak ingin ambil tahu lagi soal Cencen. Dengan demikian, koherensi hasil atau simpulan pada dialog SP(6) jadi dalam naskah drama karangan siswa sebagai sarana yang saling keterhubungan antardialog satu dengan dialog lainnya, sehingga koherensi hasil atau simpulan jadi menjadi sarana yang koheren dalam naskah drama karangan siswa.

\section{Koherensi Sinonim atau Padanan Kata (ibu/orangtua)}

Penggunaan sarana koherensi sinonim atau padanan kata ibu/orangtua terdapat pada kutipan dialog drama karangan siswa di bawah ini.

PPOT(1) Sinta : "Eh.. ada apa kelihatannya lagi pada serius gitu?"

PPOT(2) Tomy : "Eh kamu Sinta.. tidak kok, Lisa cerita ke aku kalau dia kemarin disuruh ibunya untuk beli barang kebutuhan dapur, tapi dia kelupaan."

PPOT(3) Lisa : "Iya, Sinta."

PPOT(4) Sinta : "Terus? Kenapa begitu saja kok kayak Jadi masalah serius gitu buat kamu Lisa?"

PPOT(5) Lisa : "Ya iya dong, itu namanya kan aku nggak ngendahin perintah Ibu aku. Kan nggak baik kalau seorang anak sering tidak memperhatikan perintah orangtuanya."

PPOT(6) Tomy : "Betul tu.. harusnya Lisa nggak suka lupa gitu."

PPOT(7) Sinta : "Yea elah.. kalau cuman begitu saaja aku sering. Ngapain juga urusan kecil begitu saja kalian pikir sampai segitunya."

PРОT(8) Tomy : "Mengapa kamu seperti itu sih Sinta? Ya sudah seharusnya Lisa menyesal, itukan tidak bagus 
namannya. Tidak memperdulikan perintah orangtua."

Dari nomor dialog РРОТ(5), РРОТ(8). dapat diketahui terdapat sarana koherensi berupa sinonim atau padanan kata dalam dialog di atas yaitu ibu/orangtua. Kutipan dialog pada wacana naskah drama tersebut menjelaskan tentang masalah kecil yang terlalu dibesar-bersakan. Untuk menganalisis data di atas dapat menggunakan teknik baca markah. Pada dialog PPOT(5), PPOT(8) kata ibu/orangtua merupakan sinonim atau padanan kata pada dialog Lisa dan Tomy yang memiliki hubungan padanan kata antardialognya. Penggunaan sinonim atau padanan kata sebagai satuan bahasa khususnya kata atau frasa yang bentuknya berbeda tetapi maknanya sama atau hampir sama. Dengan demikian, koherensi sinonim atau padanan kata pada dialog РРОТ(5), РРОТ(8) ibu/orangtua dalam naskah drama karangan siswa sebagai sarana yang saling keterhubungan antardialog satu dengan dialog lainnya, sehingga koherensi sinonim atau padanan kata ibu/orangtua menjadi sarana yang koheren dalam naskah drama karangan siswa.

\section{PENUTUP}

\section{Kesimpulan}

Berdasarkan hasil penelitian yang telah dilakukan mengenai penggunaan peranti kohesi dan koherensi pada naskah drama karangan siswa kelas VIII SMPN 7 Kota Bengkulu, dapat disimpulkan bahwa terdapat sebelas jenis penggunaan peranti kohesi gramatikal, dan tiga jenis peranti kohesi leksikal. Dalam naskah drama ini penggunaan peranti kohesi gramatikal lebih sering ditemukan dibandingkan dengan kohesi leksikal. Hal ini dikarenakan kohesi gramatikal yang melibatkan penggunaan unsur-unsur kaidah bahasa, dituntut keberadaannya untuk memenuhi persyaratan gramatikal. Serta terdapat sepuluh jenis sarana koherensi yang membentuk keutuhan dari dialog naskah drama karangan siswa kelas VIII SMPN 7 Kota Bengkulu.

Penggunaan bentuk peranti kohesi dan sarana kekoherensian pada dialog naskah drama karangan siswa dapat dilihat di bawah ini.

1. Bentuk peranti kohesi gramatikal meliputi: (1) pronomina orang pertama tunggal yaitu saya, dan $a k u$, (2) pronomina orang pertama jamak yaitu kami, dan kita, (3) pronomina orang kedua tunggal yaitu kamu, dan kau, (4) pronomina orang kedua jamak kalian, (5) pronomina orang ketiga tunggal yaitu dia, (6) pronomina orang ketiga jamak yaitu mereka, (7) pronomina petunjuk yaitu di sana, di sini itu, dan ini, (8) pronomina Empunya yaitu $m u, k u$, dan nya. (9) Peranti Subtitusi yaitu begitu, itu, seperti itu, dan sama. (10) Peranti Elipsis terdapat bagian yang dihilangkan yaitu kata sama Jefri. (11) Peranti Konjungsi terdiri dari, konjungsi adversatif yaitu tetapi, konjungsi kasual yaitu karena, konjungsi koordinatif yaitu dan dan atau, konjungsi subordinatif yaitu kalau, konjungsi korelatif yaitu baik/maupun, konjungsi temporal yaitu sebelum.

2. Bentuk peranti kohesi leksikal meliputi: (1) repetisi dimanfaatkan untuk memberikan penekanan pada satuan lingual yang dianggap penting yaitu kata mengikuti perlombaan (2) sinonim digunakan untuk menjalin hubungan makna yang sepadan antara satuan lingual yang satu dengan satuan lingual yang lain dalam naskah drama tersebut yaitu kata ibu/orangtua (3) antonim mencakup konsep yang betul-betul berlawanan sampai yang hanya kontras maknanya yaitu kata berteman dan bermusuhan. 
3. Bentuk sarana koherensi yang ditemukan dalam naskah drama karangan siswa kelas VIII SMPN 7 Kota Bengkulu meliputi: (1) Sarana koherensi penambahan yaitu dan, juga, (2) Sarana koherensi repetisi atau pengulangan yaitu kata mengikuti perlombaan, (3) Sarana koherensi kontras atau pertentangan yaitu tetapi, (4) Sarana koherensi rentetan atau seri yaitu akhirnya, (5) Sarana koherensi komperasi atau perbandingan yaitu sama saja, (6) Sarana koherensi hasil atau simpulan yaitu jadi, (7) Sarana koherensi sinonim atau padanan kata, (8) Sarana koherensi penekanan yaitu malah, (9) Sarana koherensi hubungan sebab akibat yaitu karena, dan (10) Sarana koherensi waktu yaitu waktu itu.

\section{DAFTAR PUSTAKA}

Arifin. 2010. Keutuhan Wacana. Jakarta: Kompas Gramedia.

Darma, Y. A. 2009. Analisis Wacana. Bandung: Yrama Widya.

Eriyanto. 2001. Analisis Wacana. Yogyakarta: Pelangi Aksara .

Setiawan, T. 2011. Wacana Bahasa Indonesia . Jakarta: Universitas Terbuka.

Tarigan, H. G. 1987. Pengajaran Wacana. Bandung: Angkasa. 